\title{
Studies on the Intestinal Absorption and Excretion of Calcium and Phosphorus in the Pig
}

\section{The Intestinal Absorption and Excretion of Radioactive Calcium and Phosphorus}

\author{
By J. H. MOORE AND C. TYLER \\ Department of Agricultural Chemistry, University of Reading
}

(Received I7 August 1954)

In the preceding paper (Moore \& Tyler, I 955) two main drawbacks were pointed out to the use of the Bergeim technique for investigating the intestinal absorption and excretion of calcium and phosphorus. Firstly, that it is impossible to determine by analysis of the gastro-intestinal contents the exact section of the tract where absorption of $\mathrm{Ca}$ and $\mathrm{P}$ is most rapid, mainly because of the lack of a satisfactory reference substance. Secondly, that there is no means of distinguishing between exogenous and endogenous $\mathrm{Ca}$ and $\mathrm{P}$ in the gastro-intestinal contents. It seemed feasible that these two difficulties might be overcome to a certain extent by the use of radioactive isotopes of $\mathrm{Ca}$ and $\mathrm{P}$.

The absorption of $\mathrm{Ca}$ and $\mathrm{P}$ at a particular point along the tract from a feed containing ${ }^{45} \mathrm{Ca}$ and ${ }^{32} \mathrm{P}$ should be indicated by an increase in the specific activity of $\mathrm{Ca}$ and $\mathrm{P}$ in the wall of the gastro-intestinal tract. On the other hand, if the body tissues contain ${ }^{45} \mathrm{Ca}$ and ${ }^{32} \mathrm{P}$ and the gastro-intestinal tract is completely cleared of exogenous ${ }^{45} \mathrm{Ca}$ and ${ }^{32} \mathrm{P}$ it should be possible to determine the endogenous $\mathrm{Ca}$ and $\mathrm{P}$ in each section of the gastro-intestinal tract if the specific activity of the $\mathrm{Ca}$ and $\mathrm{P}$ in the blood is known.

\section{Technique and procedure}

EXPERIMENTAL

The pigs used in this experiment were housed and fed as described previously (Moore \& Tyler, 1955), with the exception that the mineral supplement of calcium carbonate was replaced by calcium phosphate, at the rate of $2 \%$ of the diet, since it was desired to feed both radioactive $\mathrm{Ca}$ and $\mathrm{P}$.

In order to study the absorption of $\mathrm{Ca}$ and $\mathrm{P}$ two pigs (nos. 9 and 10 ), somewhat smaller than those used in the previous experiment, received, per meal, $500 \mathrm{~g}$ basal ration, $10.0 \mathrm{~g}$ inactive calcium phosphate and $0.5 \mathrm{~g}$ sodium chloride for a period of Io days. The calcium phosphate fed during this period was the ordinary laboratory chemical and had a Ca: $\mathrm{P}$ ratio of $2 \cdot 03$. The calcium phosphate supplement of the meal fed to the pigs at 9.30 a.m. on the I th day contained radioactive $\mathrm{Ca}$ and $\mathrm{P}$.

The radioactive calcium phosphate, which was prepared in the laboratory from calcium oxide containing ${ }^{45} \mathrm{Ca}$ and a carrier-free solution containing ${ }^{32} \mathrm{P}$, had a $\mathrm{Ca}: \mathrm{P}$ ratio of 1.99 . The specific activity of the $\mathrm{Ca}$ in the calcium phosphate so prepared was 14,900 counts $/ \mathrm{min} / \mathrm{mg}$ and of the $P, 9300$ counts $/ \mathrm{min} / \mathrm{mg}$. 
Pigs nos. 9 and 10 were slaughtered $4 \mathrm{~h}$ after they began to eat the meal containing radioactive $\mathrm{Ca}$ and $\mathrm{P}$ and the gastro-intestinal tracts were removed and divided as described by Moore \& Tyler (1955). The contents were removed from each section of the tract and immediately weighed. After mixing in a Waring Blendor, the $\mathrm{pH}$ of samples of the feed and gastro-intestinal contents was determined. Subsequently, the material was dried, ground and analysed for total $\mathrm{Ca}$ and $\mathrm{P}$, radioactive $\mathrm{Ca}$ and $\mathrm{P}$ and phytate phosphorus.

The gastro-intestinal walls of pigs nos. 9 and to were washed completely free from food residues, and connective and fatty tissues were removed as completely as possible. It was found practicable to divide certain of the five sections of the small intestine into further subsections. Section I was divided into three subsections, each about $90 \mathrm{~cm}$ long, section 3 into two subsections each about $50 \mathrm{~cm}$ long and section 5 into two subsections each about $38 \mathrm{~cm}$ long. Each segment of the gastro-intestinal wall was dried, weighed and analysed for total and radioactive $\mathrm{Ca}$ and $\mathrm{P}$.

In order to study the intestinal secretion and possible excretion of $\mathrm{Ca}$ and $\mathrm{P}$ two more pigs (nos. II and I2) were fed for IO days on a diet similar to that received by pigs nos. 9 and 10. During the whole of this ro-day period the calcium-phosphate supplement containing ${ }^{45} \mathrm{Ca}$ and ${ }^{32} \mathrm{P}$ was fed with each meal in order to obtain a concentration of these elements in the body tissues. The specific activity of the Ca in the supplement fed to pigs nos. II and I 2 was 1863 counts $/ \mathrm{min} / \mathrm{mg}$ and of the $P$ $\times 163$ counts $/ \mathrm{min} / \mathrm{mg}$.

After Io days the radioactive calcium phosphate in the diet of pigs no. II and 12 was replaced by ordinary inactive calcium phosphate for a further 4 days so that all exogenous radioactive $\mathrm{Ca}$ and $\mathrm{P}$ was removed from the gastro-intestinal tract. According to Lenkeit (1931) and Lund (1945) a period of 4 days after ingestion is necessary for complete excretion of residues of a meal from the gastro-intestinal tract of a pig. On the 15 th day, $4 \mathrm{~h}$ after the morning feed which also contained inactive calcium phosphate, pigs nos. II and I2 were slaughtered and the gastro-intestinal contents submitted to the same procedure as with pigs nos. 9 and Io. In addition, the specific activity of the $\mathrm{Ca}$ and $\mathrm{P}$ in the serum was determined.

The solubilities of $\mathrm{Ca}$ and $\mathrm{P}$ were not determined in the gastro-intestinal contents of pigs nos. 9-12, as the material available was insufficient. In order to determine the solubility of these elements in the tract of pigs that received a calcium-phosphate supplement two pigs (nos. 13 and 14 ) were fed for ro days on a diet containing inactive calcium phosphate. They were slaughtered $4 \mathrm{~h}$ after the morning feed on the IIth day and the feed and gastro-intestinal contents were treated and analysed as described previously (Moore \& Tyler, 1955).

\section{Methods of analysis}

The $\mathrm{pH}$, total $\mathrm{Ca}$ and $\mathrm{P}$, soluble $\mathrm{Ca}$ and $\mathrm{P}$, and phytate phosphorus were determined by the methods previously described (Moore \& Tyler, 1955).

The specific activity of $\mathrm{Ca}$ was determined in a sample of calcium carbonate obtained by precipitation of the $\mathrm{Ca}$ contained in nitric-perchloric acid digests as oxalate and conversion to calcium carbonate by ignition in an electric muffle at 
$475^{-525^{\circ}}$. A portion of the calcium carbonate was finely ground and mounted on a weighed aluminium disk using a solution of collodion in acetone. The radioactivity was measured by means of an end-window type Geiger-Muller counter. The results were corrected for decay, self-absorption and background count and expressed as counts/min/mg Ca.

The specific activity of $\mathbf{P}$ was determined in solution by means of an annular counter of ro $\mathrm{ml}$. capacity. The results were corrected for decay and background count and expressed as counts/min/mg $P$.

\section{RESULTS}

$p H$. The $\mathrm{pH}$ values of the gastro-intestinal contents of the six pigs used in this experiment are given in Table $\mathrm{I}$. The results were similar to those obtained with pigs nos. 3 and 4 of the previous experiment which were also slaughtered $4 h$ after they began to feed but had received a mineral supplement of calcium carbonate.

Table r. pH of the feed and of the gastro-intestinal contents of pigs nos. 9-14

Pig no.

Feed

Stomach: section I section 2

Small intestine: section $\mathrm{I}$

$$
\text { section } 2
$$
section 3 section 4 section 5

Caecum: section I section 2

Colon: section $\mathrm{r}$ section 2

Rectum

For description of sections see p. 82 .

However, $4 \mathrm{~h}$ after feeding the $\mathrm{pH}$ values of the contents of the caecum, colon and rectum of the pigs that had received calcium phosphate in the diet generally tended to be somewhat lower than those observed in the corresponding sections of the intestine of the pigs that had received a diet containing calcium carbonate.

Total calcium and phosphorus. The total $\mathrm{Ca}$ and $\mathrm{P}$ as a percentage of the dry matter of the feed and gastro-intestinal contents of pigs nos. 9-I 4 are given in Table 2. Both $\mathrm{Ca}$ and $\mathrm{P}$ were removed preferentially from the stomach of all the pigs during the first $4 \mathrm{~h}$ of digestion. Owing to this and to the fact that $\mathrm{Ca}$ and $\mathrm{P}$ probably moved along the intestine at a more rapid rate than the dry matter it was only possible to draw very limited conclusions from these results, as already fully discussed in the previous paper (Moore \& Tyler, I955).

Solubility of calcium and phosphorus. The percentage solubility of the $\mathrm{Ca}$ and $\mathrm{P}$ in the feed and gastro-intestinal contents of pigs nos. 13 and 14 are given in Table 3 , 


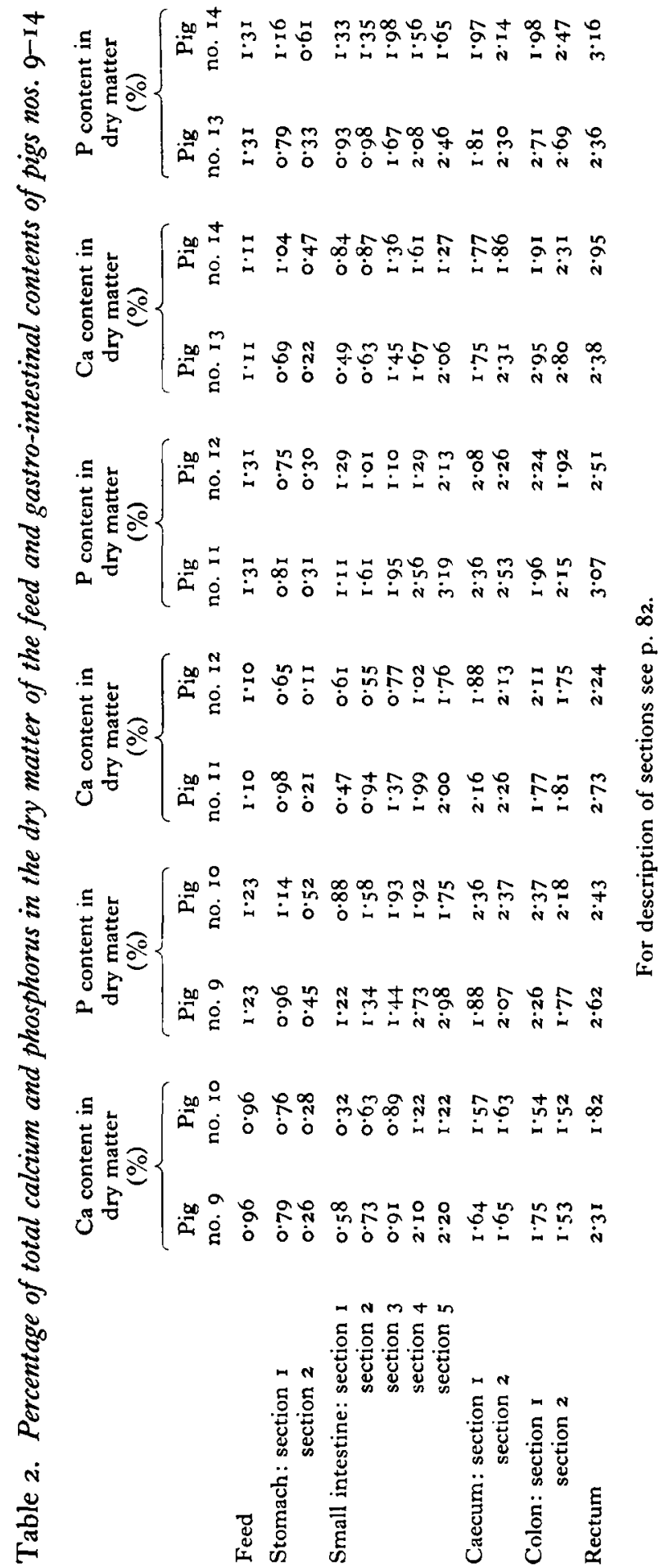


and the changes in solubility are similar to those noted for pigs nos. 3 and 4 in the previous paper (Moore \& Tyler, 1955). As might be expected, the solubility of $P$ in the gastro-intestinal contents of the pigs given calcium phosphate in the diet was considerably greater than in the corresponding sections in the pigs that had received a mineral supplement of calcium carbonate. The solubility of both $\mathrm{Ca}$ and $\mathrm{P}$ in the contents of the caecum was noticeably higher in pigs nos. I 3 and 14 than in pigs nos. 3 and 4 of the previous paper. This finding was consistent with the lower $\mathrm{pH}$ observed in the caecal contents of the pigs given calcium phosphate.

Table 3. Percentage solubility of calcium and phosphorus and concentration of $\mathrm{Ca}$ and $P$ in the liquid phase of the gastro-intestinal contents of pigs nos. 13 and 14

\begin{tabular}{|c|c|c|c|c|c|c|c|c|}
\hline & \multicolumn{4}{|c|}{ Solubility } & \multicolumn{4}{|c|}{ Concentration in liquid phase } \\
\hline & \multicolumn{2}{|c|}{$\begin{array}{c}\mathrm{Ca} \\
(\%)\end{array}$} & \multicolumn{2}{|c|}{$\underset{(\%)}{P}$} & \multicolumn{2}{|c|}{$\begin{array}{c}\mathrm{Ca} \\
(\mathrm{mg} / \mathrm{roO} \mathrm{ml} .)\end{array}$} & \multicolumn{2}{|c|}{$\underset{(\mathrm{mg} / \mathrm{I} 00 \mathrm{ml} .)}{\mathbf{P}}$} \\
\hline & $\begin{array}{c}\text { Pig } \\
\text { no. } 13\end{array}$ & $\begin{array}{c}\text { Pig } \\
\text { no. I4 }\end{array}$ & $\begin{array}{c}\text { Pig } \\
\text { no. I } 3\end{array}$ & $\begin{array}{l}\text { Pig } \\
\text { no. } 14\end{array}$ & $\begin{array}{l}\text { Pig } \\
\text { no. } 13\end{array}$ & $\begin{array}{l}\text { Pig } \\
\text { no. } 14\end{array}$ & $\begin{array}{c}\text { Pig } \\
\text { no. } \times 3\end{array}$ & $\begin{array}{l}\text { Pig } \\
\text { no. } 14\end{array}$ \\
\hline Feed & $6 \cdot 02$ & 6.02 & $43 \cdot 7$ & 43.7 & $2 I \cdot 6$ & $2 I \cdot 6$ & 186 & 186 \\
\hline $\begin{array}{r}\text { Stomach: section I } \\
\text { section } 2\end{array}$ & $\begin{array}{l}34 \cdot 7 \\
81 \cdot 2\end{array}$ & $\begin{array}{l}20 \cdot 5 \\
78 \cdot 2\end{array}$ & $\begin{array}{l}58 \cdot 7 \\
95 \cdot 6\end{array}$ & $\begin{array}{l}44 \cdot 8 \\
81 \cdot 9\end{array}$ & $\begin{array}{l}82 \cdot 6 \\
52 \cdot 4\end{array}$ & $\begin{array}{l}87 \cdot 1 \\
126\end{array}$ & $\begin{array}{l}170 \\
110\end{array}$ & $\begin{array}{l}226 \\
170\end{array}$ \\
\hline $\begin{array}{r}\text { Small intestine: } \\
\qquad \begin{array}{l}\text { section } 1 \\
\text { section } 2 \\
\text { section } 4 \\
\text { section } 5\end{array}\end{array}$ & $\begin{array}{l}36 \cdot 7 \\
35 \cdot 6 \\
18 \cdot 6 \\
9 \cdot 62 \\
9 \cdot 14\end{array}$ & $\begin{array}{l}41 \cdot 5 \\
18 \cdot 4 \\
10 \cdot 3 \\
9 \cdot 18 \\
7 \cdot 85\end{array}$ & $\begin{array}{l}97 \cdot 8 \\
62 \cdot 9 \\
62 \cdot 0 \\
41 \cdot 6 \\
34 \cdot 8\end{array}$ & $\begin{array}{l}87 \cdot 9 \\
78 \cdot 2 \\
36 \cdot 2 \\
52 \cdot 0 \\
52 \cdot 4\end{array}$ & $\begin{array}{l}14.7 \\
28 \cdot 6 \\
25 \cdot 0 \\
24.5 \\
26 \cdot 0\end{array}$ & $\begin{array}{l}35 \cdot 3 \\
15 \cdot 6 \\
21 \cdot 2 \\
25 \cdot 0 \\
14 \cdot 8\end{array}$ & $\begin{array}{l}83 \cdot 3 \\
70 \cdot 0 \\
103 \\
141 \\
127\end{array}$ & $\begin{array}{l}127 \\
110 \\
116 \\
146 \\
138\end{array}$ \\
\hline $\begin{array}{r}\text { Caecum: section I } \\
\text { section } 2\end{array}$ & $\begin{array}{l}34 \cdot 0 \\
24 \cdot 2\end{array}$ & $\begin{array}{l}35 \cdot 8 \\
37 \cdot 0\end{array}$ & $\begin{array}{l}56 \cdot 6 \\
44 \cdot 0\end{array}$ & $\begin{array}{l}66 \cdot 5 \\
63 \cdot 1\end{array}$ & $\begin{array}{l}80 \cdot 0 \\
89 \cdot 2\end{array}$ & $\begin{array}{l}79 \cdot 0 \\
95 \cdot 3\end{array}$ & $\begin{array}{l}149 \\
172\end{array}$ & $\begin{array}{l}175 \\
200\end{array}$ \\
\hline $\begin{array}{r}\text { Colon: section } 1 \\
\text { section } 2\end{array}$ & $\begin{array}{l}11 \cdot 7 \\
8 \cdot 36\end{array}$ & $\begin{array}{c}29 \cdot 4 \\
6 \cdot 88\end{array}$ & $\begin{array}{l}28 \cdot 0 \\
26 \cdot 7\end{array}$ & $\begin{array}{l}55 \cdot 5 \\
30 \cdot 6\end{array}$ & $\begin{array}{l}71 \cdot 6 \\
55 \cdot 9\end{array}$ & $\begin{array}{l}97 \cdot 7 \\
37 \cdot 2\end{array}$ & $\begin{array}{l}172 \\
183\end{array}$ & $\begin{array}{l}205 \\
190\end{array}$ \\
\hline Rectum & $6 \cdot 63$ & $3 \cdot 83$ & $30 \cdot 0$ & $21 \cdot 5$ & $3^{8 \cdot 1}$ & $29 \cdot 8$ & I 82 & 192 \\
\hline
\end{tabular}

The percentage of dry matter in the contents of the gastro-intestinal tract of pigs nos. 13 and 14 was determined, and hence the water content was known. It was therefore possible to obtain by calculation approximate values for the concentration of $\mathrm{Ca}$ and $\mathrm{P}$ in the aqueous phase of the gastro-intestinal contents. These figures are also given in Table 3 , and will be referred to in the section dealing with radioactive $\mathrm{Ca}$ and $\mathrm{P}$.

Phytate phosphorus. The percentage of phytate phosphorus in the dry matter of the contents of the stomach and small intestine of pigs nos. 9-14 (Table 4 ) was of the same order as that obtained with pigs nos. 3 and 4 of the previous paper. However, there was a striking difference in the percentage of phytate phosphorus in the dry matter of the contents of the large intestine. It appeared that extensive hydrolysis of phytate phosphorus took place in the large intestine of the pigs given calcium phosphate, whereas there was little evidence to show that hydrolysis occurred at all in the large intestine of the pigs given calcium carbonate (Moore \& Tyler, 1955).

Radioactive calcium and phosphorus in the contents and wall of the gastro-intestinal tract of pigs nos. 9 and 10 . The counts $/ \mathrm{min} / \mathrm{mg}$ as determined in the calcium- 
carbonate samples were converted into values for the actual quantities of $\mathrm{Ca}$ using the following equation

$$
\frac{\text { counts } / \mathrm{min} / \mathrm{mg} \mathrm{Ca}}{14,900}=\frac{{ }^{45} \mathrm{Ca}}{\text { total Ca }} \text {. }
$$

The counts $/ \mathrm{min} / \mathrm{mg}$ total $P$, as determined, were first expressed as counts $/ \mathrm{min} / \mathrm{mg}$ non-phytate phosphorus. On the assumption that no phytate was synthesized in the contents of the gastro-intestinal tract the phytate $P$ should have been entirely inactive. The counts/mg non-phytate $P$ were then converted into values for the actual quantities of $\mathbf{P}$ using the following equation

$$
\frac{\text { Counts } / \mathrm{min} / \mathrm{mg} \text { non-phytate } \mathrm{P}}{9300}=\frac{{ }^{32} \mathrm{P}}{\text { non-phytate } \mathrm{P}} \text {. }
$$

The weights and percentages of ${ }^{45} \mathrm{Ca}$ and ${ }^{32} \mathrm{P}$ subsequently quoted refer to weights of labelled $\mathrm{Ca}$ and $\mathrm{P}$ of the same specific activity as that fed or, for pig's nos. I I and 12 , as that in the serum.

Table 4. Percentage of phytate $P$ in the dry matter of the feed and of the gastro-intestinal contents of pigs nos. 9-14

Pig no.

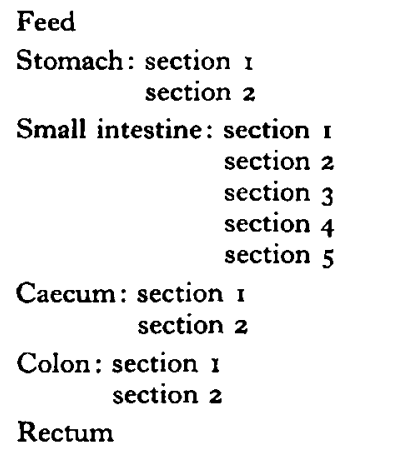

\begin{tabular}{lccccc}
\hline 9 & 10 & 11 & 12 & 13 & 14 \\
0.48 & 0.48 & 0.48 & 0.48 & 0.48 & 0.48 \\
0.13 & 0.24 & 0.10 & 0.14 & 0.21 & 0.18 \\
0.10 & 0.08 & 0.04 & 0.05 & 0.15 & 0.19 \\
0.32 & 0.22 & 0.33 & 0.32 & 0.20 & 0.36 \\
0.50 & 0.53 & 0.50 & 0.41 & 0.32 & 0.42 \\
0.47 & 0.85 & 0.76 & 0.49 & 0.68 & 0.71 \\
1.18 & 0.85 & 1.05 & 0.54 & 0.89 & 0.73 \\
1.32 & 0.86 & 0.62 & 0.82 & 0.88 & 0.60 \\
0 & 0.13 & 0.11 & 0.25 & 0.18 & 0.23 \\
0 & 0.12 & 0.15 & 0.22 & 0.26 & 0.19 \\
0.19 & 0.13 & 0.10 & 0.19 & 0.21 & 0.12 \\
0 & 0.11 & 0.05 & 0.10 & 0.27 & 0.12 \\
0.10 & 0.12 & 0.07 & 0.15 & 0.08 & 0.09
\end{tabular}

For description of sections see p. 82 .

The weight of ${ }^{45} \mathrm{Ca}$ and ${ }^{32} \mathrm{P}$ in each segment and the percentage of ${ }^{45} \mathrm{Ca}$ in the total $\mathrm{Ca}$ and of ${ }^{32} \mathrm{P}$ in the non-phytate $\mathrm{P}$ for the gastro-intestinal contents are given in Table 5 .

A secretion of $P$ into the lumen of the first section of the small intestine of pigs nos. 9 and 10 is illustrated by the large decrease in the percentage of ${ }^{32} \mathrm{P}$ in nonphytate $\mathrm{P}$ in the contents observed in the small intestine. There was a marked increase in the percentage of ${ }^{32} \mathrm{P}$ in the non-phytate $\mathrm{P}$ from sections $3-5$ of the small intestine. This seems to indicate that the actual phosphorus compounds secreted into the upper small intestine tended to be reabsorbed from the lower sections.

Consideration of the percentage of ${ }^{45} \mathrm{Ca}$ in the total $\mathrm{Ca}$ and of ${ }^{32} \mathrm{P}$ in the total $\mathrm{P}$ in the tissues of the gastro-intestinal tract of pigs nos. 9 and ro (Table 6) shows which sections were most active in the absorption of $\mathrm{Ca}$ and $\mathrm{P}$. These were for $\mathrm{Ca}$ the first and second subsections of the small intestine and for $\mathrm{P}$ the first four subsections. 
Any increase in the specific activity of $\mathrm{Ca}$ and $\mathrm{P}$ in a particular segment of the gastro-intestinal wall may be due to two factors: (1) active absorption of ${ }^{45} \mathrm{Ca}$ and ${ }^{32} \mathrm{P}$, and (2) an exchange of ${ }^{45} \mathrm{Ca}$ and ${ }^{32} \mathrm{P}$ in the intestinal content with the inactive $\mathrm{Ca}$ and $\mathrm{P}$ in the gastro-intestinal wall. Presumably the extent of exchange will depend largely upon the concentration of ${ }^{45} \mathrm{Ca}$ and ${ }^{32} \mathrm{P}$ in the liquid phase of the intestinal contents. Unfortunately, it was not possible to determine the solubility of ${ }^{45} \mathrm{Ca}$ and

Table 5. Weight of ${ }^{45} \mathrm{Ca}$ and ${ }^{32} \mathrm{P}$ and percentage of ${ }^{45} \mathrm{Ca}$ in the total $\mathrm{Ca}$ and of ${ }^{32} \mathrm{P}$ in the non-phytate $P$ of the gastro-intestinal contents of pigs nos. 9 and 10

\begin{tabular}{|c|c|c|c|c|c|c|c|c|}
\hline & \multicolumn{2}{|c|}{$\begin{array}{c}\text { Weight of }{ }^{45} \mathrm{Ca} \\
\text { in segment } \\
(\mathrm{g})\end{array}$} & \multicolumn{2}{|c|}{$\begin{array}{l}{ }^{45} \mathrm{Ca} \text { as } \\
\text { percentage of } \\
\text { total } \mathrm{Ca}\end{array}$} & \multicolumn{2}{|c|}{$\begin{array}{l}\text { Weight of }{ }^{32} \mathrm{P} \\
\text { in segment } \\
(\mathrm{g})\end{array}$} & \multicolumn{2}{|c|}{$\begin{array}{c}{ }^{32} \mathrm{P} \text { as } \\
\text { percentage of } \\
\text { non-phytate } \mathrm{P}\end{array}$} \\
\hline & $\begin{array}{l}\text { Pig } \\
\text { no. } 9\end{array}$ & $\begin{array}{l}\text { Pig } \\
\text { no. Io }\end{array}$ & $\begin{array}{l}\text { Pig } \\
\text { no. } 9\end{array}$ & $\begin{array}{l}\text { Pig } \\
\text { no. Io }\end{array}$ & $\begin{array}{l}\text { Pig } \\
\text { no. } 9\end{array}$ & $\begin{array}{l}\text { Pig } \\
\text { no. } 10\end{array}$ & $\begin{array}{l}\text { Pig } \\
\text { no. } 9\end{array}$ & $\begin{array}{l}\text { Pig } \\
\text { no. Io }\end{array}$ \\
\hline Feed & - & $\cdots$ & $75 \cdot 5$ & $75 \cdot 5$ & - & - & $48 \cdot 2$ & $48 \cdot 2$ \\
\hline $\begin{array}{r}\text { Stomach: section I } \\
\text { section } 2\end{array}$ & $\begin{array}{l}0.59 \\
0.25\end{array}$ & $\begin{array}{l}0.59 \\
0.18\end{array}$ & $\begin{array}{l}83 \cdot 8 \\
94 \cdot 2\end{array}$ & $\begin{array}{l}79 \cdot 4 \\
84.6\end{array}$ & $\begin{array}{l}0.34 \\
0.29\end{array}$ & $\begin{array}{l}0.44 \\
0.32\end{array}$ & $\begin{array}{l}46 \cdot 0 \\
83 \cdot 7\end{array}$ & $\begin{array}{l}49 \cdot 6 \\
97 \cdot 7\end{array}$ \\
\hline $\begin{array}{r}\text { Small intestine: } \\
\text { section } 1 \\
\text { section } 2 \\
\text { section } 3 \\
\text { section } 4 \\
\text { section } 5\end{array}$ & $\begin{array}{l}0.04 \\
0.10 \\
0.10 \\
0.33 \\
0.18\end{array}$ & $\begin{array}{l}0.02 \\
0.07 \\
0.05 \\
0.14 \\
0.17\end{array}$ & $\begin{array}{l}80 \cdot 6 \\
80 \cdot 4 \\
76 \cdot 5 \\
75 \cdot 3 \\
70 \cdot 2\end{array}$ & $\begin{array}{l}89 \cdot 8 \\
88 \cdot 7 \\
76 \cdot 8 \\
77 \cdot 4 \\
79 \cdot 5\end{array}$ & $\begin{array}{l}0.02 \\
0.04 \\
0.04 \\
0.14 \\
0.10\end{array}$ & $\begin{array}{l}0.02 \\
0.04 \\
0.03 \\
0.06 \\
0.08\end{array}$ & $\begin{array}{l}30 \cdot 7 \\
26 \cdot 7 \\
25 \cdot 9 \\
43 \cdot 3 \\
53 \cdot 1\end{array}$ & $\begin{array}{l}35 \cdot 9 \\
29 \cdot 4 \\
32 \cdot 0 \\
39 \cdot 8 \\
47 \cdot 6\end{array}$ \\
\hline $\begin{array}{r}\text { Caecum: section } 1 \\
\text { section } 2\end{array}$ & $\begin{array}{l}0.06 \\
0.09\end{array}$ & $\begin{array}{l}0.12 \\
0.13\end{array}$ & $\begin{array}{l}35^{-1} \\
33 \cdot 7\end{array}$ & $\begin{array}{l}55^{-1} \\
4^{8} \cdot 2\end{array}$ & $\begin{array}{l}0.03 \\
0.05\end{array}$ & $\begin{array}{l}0.06 \\
0.06\end{array}$ & $\begin{array}{l}15 \cdot 5 \\
14 \cdot 8\end{array}$ & $\begin{array}{l}18 \cdot 4 \\
16 \cdot 7\end{array}$ \\
\hline $\begin{array}{r}\text { Colon: section I } \\
\text { section } 2\end{array}$ & $\begin{array}{l}0.19 \\
0.11\end{array}$ & $\begin{array}{l}0.09 \\
0.15\end{array}$ & $\begin{array}{l}32 \cdot 9 \\
18 \cdot 5\end{array}$ & $\begin{array}{l}35 \cdot 7 \\
36 \cdot 2\end{array}$ & $\begin{array}{l}0.10 \\
0.05\end{array}$ & $\begin{array}{l}0.06 \\
0.07\end{array}$ & $\begin{array}{l}15 \cdot 0 \\
7.17\end{array}$ & $\begin{array}{l}15 \cdot 4 \\
11 \cdot 9\end{array}$ \\
\hline Rectum & 0.004 & 0.05 & 0.27 & 5.02 & $\circ$ & 0.12 & 0 & $10 \cdot 3$ \\
\hline
\end{tabular}

For description of sections see p. 82 ; for definition of ${ }^{45} \mathrm{Ca}$ and ${ }^{32} \mathrm{P}$ see p. 86 .

Table 6. Percentage of ${ }^{45} \mathrm{Ca}$ in the total $\mathrm{Ca}$ and of ${ }^{32} \mathrm{P}$ in the total $\mathrm{P}$ in the tissues of the gastro-intestinal tract of pigs nos. 9 and 10

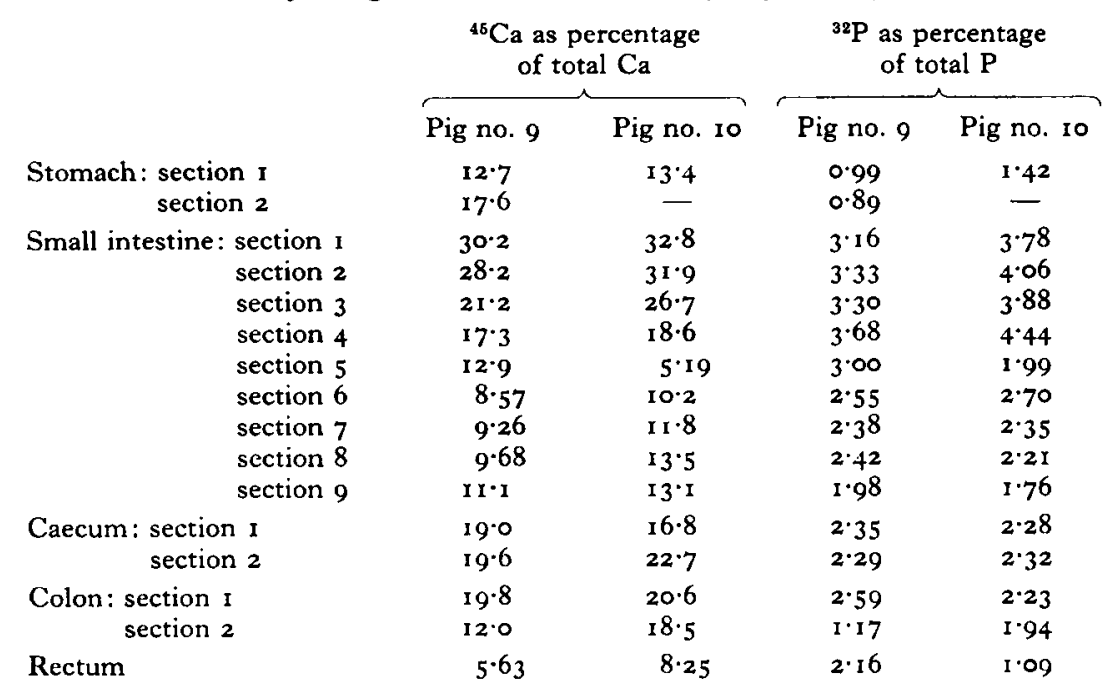

For description of sections see p. 82 ; for definition of ${ }^{45} \mathrm{Ca}$ and ${ }^{32} \mathrm{P}$ see p. 86 . 
${ }^{32} \mathrm{P}$ in the gastro-intestinal contents of pigs nos. 9 and 10. However, values are available for pigs nos. 13 and 14 which were fed on a diet almost identical with that of pigs nos. 9 and 10.

The concentration of $\mathrm{P}$ in the liquid phase of the contents of the first and second sections of the small intestine of pigs nos. 13 and 14 was lower than in the remaining three sections. The percentage of ${ }^{32} \mathrm{P}$ in the non-phytate $\mathrm{P}$ of the contents of the upper small intestine of pigs nos. 9 and 10 was less than in the lower small intestine. In view of this, it might be expected that exchange of ${ }^{32} \mathrm{P}$ would be more extensive in the lower than in the upper small intestine. Therefore, it appeared that the high percentage of ${ }^{32} \mathrm{P}$ in the total $\mathrm{P}$ of the wall of the first four subsections of the small intestine of pigs nos. 9 and 10 could be safely attributed to the more extensive absorption of the $\mathrm{P}$ derived from the calcium-phosphate supplement.

A similar argument may be applied to the corresponding $\mathrm{Ca}$ figures, for the concentration of $\mathrm{Ca}$ in the liquid phase of the contents of the first four sections of the small intestine of pigs nos. I 3 and 14 was fairly constant, whereas there was little difference in the specific activity of $\mathrm{Ca}$ in the contents of the first two sections of the small intestine of pigs nos. 9 and 10. Thus, absorption of Ca derived from the calciumphosphate supplement seems to have been most active in the first two subsections of the small intestine.

There was also a marked increase in the percentage of ${ }^{45} \mathrm{Ca}$ in the total $\mathrm{Ca}$ of the wall of the caecum and the first section of the colon of pigs nos. 9 and ro. The concentration of $\mathrm{Ca}$ in the liquid phase of the contents of the caecum and the first section of the colon of pigs nos. 13 and 14 was more than four times as great as in the contents of the small intestine, and the increase from the fifth section of the small intestine to the first section of the caecum was very abrupt. In the contents of the first and second sections of the caecum and the first section of the colon of pigs nos. 9 and ro the average percentage of ${ }^{45} \mathrm{Ca}$ in the total $\mathrm{Ca}$ was $45^{\circ} \mathrm{I}, 40.9$ and 34.3 respectively. Hence, the higher specific activity of $\mathrm{Ca}$ in the wall of the caecum and the first section of the colon in pigs nos. 9 and 10 was probably due solely to exchange. It is interesting to note that in pigs nos. 13 and 14 the Ca concentration in the liquid phase of the contents of the colon decreased markedly in passing from the first to the second section. A corresponding decrease in the specific activity of $\mathrm{Ca}$ in the wall of the colon of pigs nos. 9 and Io occurred in passing from the first to the second section. The percentage of total $\mathrm{Ca}$ (mean 0.017 ) and of total $\mathrm{P}$ (mean $\mathrm{x} \cdot 06$ ) in the dry matter of the gastro-intestinal wall were fairly constant along the whole length of the tract.

Radioactive calcium and phosphorus in the contents of the gastro-intestinal tract of pigs nos. I I and I2. Since I $\mathrm{mg}$ of $\mathrm{Ca}$ in the serum of pigs nos. I I and $\mathrm{I} 2$ had counts of $520 / \mathrm{min}$ and $570 / \mathrm{min}$ respectively, the counts $/ \mathrm{min} / \mathrm{mg}$ as determined in the calciumcarbonate samples were converted into the values for actual quantities of $\mathrm{Ca}$ using the following equations:

$$
\begin{aligned}
& \text { pig no. I I, } \frac{\text { counts } / \mathrm{min} / \mathrm{mg} \mathrm{Ca}}{520}=\frac{{ }^{45} \mathrm{Ca}}{\text { total Ca }}, \\
& \text { pig no. I2, }
\end{aligned}
$$


The specific activities of $P$ in the serum of pigs nos. II and $I 2$ were 85.2 and 96.5 counts $/ \mathrm{min} / \mathrm{mg}$ respectively. The counts $/ \mathrm{min} / \mathrm{mg}$ for total $\mathrm{P}$, as determined, were first expressed as counts $/ \mathrm{min} / \mathrm{mg}$ non-phytate $P$, and then converted to the values for actual quantities of $P$ using the following equations:

$$
\begin{aligned}
& \text { pig no. I I, } \frac{\text { counts } / \mathrm{min} / \mathrm{mg} \text { non-phytate } \mathrm{P}}{85^{\cdot 2}}=\frac{{ }^{32} \mathrm{P}}{\text { non-phytate } \mathrm{P}}, \\
& \text { pig no. I }, \quad \frac{\text { counts } / \mathrm{min} / \mathrm{mg} \text { non-phytate } \mathrm{P}}{96 \cdot 5}=\frac{{ }^{32} \mathrm{P}}{\text { non-phytate } \mathrm{P}} .
\end{aligned}
$$

The weights of ${ }^{45} \mathrm{Ca}$ and ${ }^{32} \mathrm{P}$ in each segment and the percentages of ${ }^{45} \mathrm{Ca}$ in the total $\mathrm{Ca}$ and of ${ }^{32} \mathrm{P}$ in the non-phytate $\mathrm{P}$ for the gastro-intestinal contents are given in Table 7 .

Table 7. Weight of ${ }^{45} \mathrm{Ca}$ and ${ }^{32} \mathrm{P}$ and percentage of ${ }^{45} \mathrm{Ca}$ in the total $\mathrm{Ca}$ and of

\begin{tabular}{|c|c|c|c|c|c|c|c|c|}
\hline & \multicolumn{2}{|c|}{$\begin{array}{l}\text { Weight of }{ }^{45} \mathrm{Ca} \\
\text { in segment } \\
\text { (g) }\end{array}$} & \multicolumn{2}{|c|}{$\begin{array}{l}{ }^{45} \mathrm{Ca} \text { as } \\
\text { percentage of } \\
\text { total } \mathrm{Ca}\end{array}$} & \multicolumn{2}{|c|}{$\begin{array}{l}\text { Weight of }{ }^{32} \mathrm{P} \\
\text { in segment } \\
(\mathrm{g})\end{array}$} & \multicolumn{2}{|c|}{$\begin{array}{c}\text { 32P as } \\
\text { percentage of } \\
\text { non-phytate } \mathrm{P}\end{array}$} \\
\hline & $\begin{array}{l}\text { Pig } \\
\text { no. II }\end{array}$ & $\begin{array}{l}\text { Pig } \\
\text { no. I2 }\end{array}$ & $\begin{array}{l}\text { Pig } \\
\text { no. II }\end{array}$ & $\begin{array}{l}\text { Pig } \\
\text { no. } 12\end{array}$ & $\begin{array}{l}\text { Pig } \\
\text { no. I I }\end{array}$ & $\begin{array}{l}\text { Pig } \\
\text { no. } 12\end{array}$ & $\begin{array}{l}\text { Pig } \\
\text { no. II }\end{array}$ & $\begin{array}{l}\text { Pig } \\
\text { no. } 12\end{array}$ \\
\hline Feed & - & - & 0 & 0 & - & - & $\circ$ & $\circ$ \\
\hline $\begin{array}{r}\text { Stomach: section I } \\
\text { section } 2\end{array}$ & $\begin{array}{l}0.01 \\
0.003\end{array}$ & $\begin{array}{l}0.003 \\
0.001\end{array}$ & $\begin{array}{l}x \cdot 43 \\
2 \cdot 94\end{array}$ & $\begin{array}{l}0.66 \\
3.64\end{array}$ & $\begin{array}{l}\circ \\
\circ\end{array}$ & $\begin{array}{l}0 \\
\circ\end{array}$ & $\begin{array}{l}\circ \\
0\end{array}$ & $\begin{array}{l}\circ \\
\circ\end{array}$ \\
\hline $\begin{array}{r}\text { Small intestine: } \\
\text { section } 1 \\
\text { section } 2 \\
\text { section } 3 \\
\text { section } 4 \\
\text { section } 5\end{array}$ & $\begin{array}{l}0.004 \\
0.005 \\
0.01 \\
0.02 \\
0.006\end{array}$ & $\begin{array}{l}0.004 \\
0.009 \\
0.006 \\
0.009 \\
0.02\end{array}$ & $\begin{array}{l}6 \cdot 58 \\
7 \cdot 50 \\
4 \cdot 41 \\
4 \cdot 18 \\
5 \cdot 12\end{array}$ & $\begin{array}{l}6 \cdot 92 \\
8 \cdot 21 \\
4 \cdot 97 \\
4 \cdot 51 \\
4 \cdot 19\end{array}$ & $\begin{array}{l}0.03 \\
0.01 \\
0.02 \\
0.02 \\
0.005\end{array}$ & $\begin{array}{l}0.03 \\
0.03 \\
0.01 \\
0.01 \\
0.02\end{array}$ & $\begin{array}{l}31 \cdot 8 \\
16 \cdot 3 \\
5 \cdot 87 \\
6 \cdot 45 \\
3 \cdot 27\end{array}$ & $\begin{array}{l}27 \cdot 8 \\
22 \cdot 7 \\
14 \cdot 3 \\
9 \cdot 76 \\
5 \cdot 91\end{array}$ \\
\hline $\begin{array}{r}\text { Caecum: } \\
\text { section } 1 \\
\text { section } 2\end{array}$ & $\begin{array}{l}0.03 \\
0.07\end{array}$ & $\begin{array}{l}0.03 \\
0.05\end{array}$ & $\begin{array}{l}5 \cdot 65 \\
7 \cdot 66\end{array}$ & $\begin{array}{l}5 \cdot 76 \\
7 \cdot 01\end{array}$ & $\begin{array}{l}0.02 \\
0.03\end{array}$ & $\begin{array}{l}0.02 \\
0.03\end{array}$ & $\begin{array}{l}3 \cdot 38 \\
3 \cdot 03\end{array}$ & $\begin{array}{l}3 \cdot 48 \\
3 \cdot 82\end{array}$ \\
\hline $\begin{array}{r}\text { Colon: section I } \\
\text { section } 2\end{array}$ & $\begin{array}{l}0.09 \\
0.13\end{array}$ & $\begin{array}{l}0.04 \\
0.08\end{array}$ & $\begin{array}{l}9.07 \\
10.4\end{array}$ & $\begin{array}{l}7 \cdot 82 \\
9 \cdot 29\end{array}$ & $\begin{array}{l}0.05 \\
0.10\end{array}$ & $\begin{array}{l}0.03 \\
0.06\end{array}$ & $\begin{array}{l}5 \cdot 02 \\
6.39\end{array}$ & $\begin{array}{l}5 \cdot 04 \\
6 \cdot 41\end{array}$ \\
\hline Rectum & 0.29 & $0 \cdot 18$ & $8 \cdot 56$ & $7 \cdot 90$ & 0.15 & 0.12 & 4.00 & $4 \cdot 8 I$ \\
\hline
\end{tabular}
${ }^{32} P$ in the non-phytate $P$ of the gastro-intestinal contents of pigs nos. I I and I2

For description of sections see p. 82 ; for definition of ${ }^{45} \mathrm{Ca}$ and ${ }^{33} \mathrm{P}$ see p. 86 .

The stomach contents of pigs nos. II and 12 contained no ${ }^{32} \mathrm{P}$ but small amounts of ${ }^{45} \mathrm{Ca}$. The ${ }^{45} \mathrm{Ca}$ in the stomach contents may have been derived from the gastric juice since Trautmann \& Kirchhoff (1937) found that the concentration of $\mathrm{Ca}$ in the gastric juice of the pig was $5^{-10} \mathrm{mg} / 100 \mathrm{ml}$. The percentage of ${ }^{32} \mathrm{P}$ in the dry matter and the percentage of ${ }^{32} \mathrm{P}$ in the non-phytate $\mathbf{P}$ of the contents of the first section of the small intestine showed that there was a considerable secretion of $P$ into this part of the intestine. A smaller but definite secretion of $\mathrm{Ca}$ into the upper small intestine was also apparent from the percentage of ${ }^{45} \mathrm{Ca}$ in the total $\mathrm{Ca}$ of the intestinal contents.

Increases in the percentage of ${ }^{45} \mathrm{Ca}$ in the total $\mathrm{Ca}$ and the percentage of ${ }^{32} \mathrm{P}$ in the non-phytate $P$ of the contents of the large intestine from the first section of the caecum to the rectum were small. Such increases might easily be accounted for by exchange between ${ }^{45} \mathrm{Ca}$ and ${ }^{32} \mathrm{P}$ in the wall of the large intestine and inactive $\mathrm{Ca}$ and 
$P$ in the contents, the reverse of which had occurred in pigs nos. 9 and 10 . There was no evidence that a controlled excretion of $\mathrm{Ca}$ and $\mathrm{P}$ through the wall of the large intestine had taken place.

\section{DISCUSSION}

The results above reported show that the absorption of $\mathrm{Ca}$ from the small intestine of the pig $4 \mathrm{~h}$ after feeding was most active from the proximal fourth and of $\mathrm{P}$ from the proximal half. These findings are in fair agreement with those reported by Hagens (1943) for pigs by a very different method of investigation. It has been found by the isolated-loop technique that $\mathrm{Ca}$ (Nicolaysen, 195I) and P (Laskowski, 1937) are absorbed to a greater extent from the upper than from the lower small intestine. Harrison \& Harrison (1951) have shown that absorption of ${ }^{45} \mathrm{Ca}$ during the $4{ }^{-24} \mathrm{~h}$ period after administration of the isotope by stomach tube takes place from the lower small intestine or the caecum of normal and of vitamin D-treated rachitic rats. Although it seems likely that the high specific activity of $\mathrm{Ca}$ in the wall of the caecum of pigs nos. 9 and Io in the present experiment was a result of intensive exchange the possibility that absorption of $\mathrm{Ca}$ had occurred from the caecum of the pigs cannot be completely dismissed.

The results obtained from the present experiment show that $\mathrm{Ca}$ and $\mathrm{P}$ are secreted into the lumen of the upper small intestine and are reabsorbed to a certain extent in the lower section of the small intestine but there was no evidence that $\mathrm{Ca}$ and $\mathbf{P}$ are excreted through the wall of the large intestine.

As Kjerulf-Jensen (194I-2) has pointed out, it is impossible for two reasons to determine with radioactive tracers the absolute amounts of endogenous $\mathrm{Ca}$ and $\mathrm{P}$ excreted from the body by the intestine. Firstly, since the contents of the intestinal tracts of pigs nos. II and $\mathrm{I} 2$, for example, contained inactive exogenous $\mathrm{Ca}$ and $\mathrm{P}$, the specific activity of the $\mathrm{Ca}$ and $\mathrm{P}$ secreted into the upper small intestine would have been considerably greater than the specific activity of the $\mathrm{Ca}$ and $\mathrm{P}$ subsequently reabsorbed from the lower small intestine. It is certain, therefore, that the reabsorption of the secreted $\mathrm{Ca}$ and $\mathrm{P}$ in pigs nos. I I and $\mathrm{I} 2$ was more efficient than was indicated by the reabsorption of ${ }^{45} \mathrm{Ca}$ and ${ }^{32} \mathrm{P}$. Secondly, in all probability, there would be an exchange between ${ }^{45} \mathrm{Ca}$ and ${ }^{32} \mathrm{P}$ present in the tissues of the gastro-intestinal tracts of pigs nos. II and $\mathrm{I} 2$ and the inactive $\mathrm{Ca}$ and $\mathrm{P}$ in the contents.

Thus, the faecal output of endogenous $\mathrm{Ca}$ and $\mathrm{P}$ is overestimated by this and similar techniques.

More recently certain workers in this field have tended to ignore the precautions emphasized by Kjerulf-Jensen (194I-2). For instance, in experiments described by L'Heureux, Tweedy \& Zorn (1949) and Wallace, Shirley \& Davies (195 X), rats were injected with ${ }^{45} \mathrm{Ca}$ solutions and the percentage of the administered dose subsequently excreted in the urine and faeces was determined. Since the percentage of the administered dose excreted in the faeces during the collection period was greater than that excreted in the urine these workers concluded that the intestinal tract is the principal route by which $\mathrm{Ca}$ is excreted from the body. During these experiments the rats were fed on a complete diet which presumably contained adequate $\mathrm{Ca}$, so it 
seems reasonable to assume that although there would be a considerable loss of ${ }^{45} \mathrm{Ca}$ from the body through the intestine this, no doubt, would be much greater than the actual loss of endogenous $\mathrm{Ca}$.

If the conclusions of L'Heureux et al. (1949) and Wallace et al. (I95I) are correct one might have expected that analysis of the urine and faeces for total $\mathrm{Ca}$ would also have shown that the injected $\mathrm{Ca}$ was excreted from the body of the rat mainly in the faeces. Unfortunately, the excretion of total $\mathrm{Ca}$ in the urine and faeces was not determined by these workers, but it is perhaps significant that McCance \& Widdowson (1939), Nicolaysen (1934) and Baylor, Van Alstine, Keutmann \& Bassett (1950) found that injections of $\mathrm{Ca}$ did not increase the output of total faecal calcium but increased the urinary calcium excretion. Adolph \& Liang (194I), working with rats, have also produced evidence inconsistent with the view that injected $\mathrm{Ca}$ is excreted by the intestine.

It is of interest that when rats were injected with ${ }^{32} \mathrm{P}$ solutions (Cohn \& Greenberg, 1938; Gaunt, Griffith \& Irving, I941-2) the percentage of the administered dose recovered from the faeces was less than that recovered from the urine. These results, as opposed to those obtained by L'Heureux et al. (1949) and Wallace et al. (195I) with ${ }^{45} \mathrm{Ca}$, showed that excess $P$ was excreted from the body mainly in the urine. The explanation of this difference may be due partly to the fact that effective dilution of ${ }^{45} \mathrm{Ca}$ secreted into the small intestine with inactive exogenous $\mathrm{Ca}$ in the contents is greater than the effective dilution of secreted ${ }^{32} \mathrm{P}$ since intestinal contents normally contain a considerable proportion of organically bound $P$. However, this is perhaps not the whole explanation, for with pigs nos. 9 and ro of the present experiment, although the small intestine contained exogenous ${ }^{32} \mathrm{P}$ derived from the calciumphosphate supplement it seemed to be the secreted inactive $\mathbf{P}$ that was largely reabsorbed from the lower small intestine.

The present study has shown that the mineral supplement added to the basal ration of the pigs greatly influenced either directly or indirectly the extent of phytate hydrolysis in the large intestine. There was no evidence that phytate hydrolysis occurred in the large intestine of pigs when the mineral supplement consisted of calcium carbonate (Moore \& Tyler, 1955), but it was almost complete when the calcium carbonate was replaced by calcium phosphate. The reason for the greater hydrolysis of phytate in the large intestine of the pigs given calcium phosphate is rather obscure. Comparing the results of the present with the previous experiment (Moore \& 'Tyler, 1955) it was noticed that the $\mathrm{pH}$ of the contents of the large intestine was reduced by the replacement of calcium carbonate by calcium phosphate in the diet. It may have been that this lower $\mathrm{pH}$ was more conducive to the bacterial hydrolysis of phytate in the large intestine. It is unlikely that the activity of phytase originating from the feed would be appreciable in the large intestine since Hill \& Tyler (1954) have shown that phytase derived from dietary sources is permanently inhibited when subjected to $\mathrm{pH}_{3} .0$ or less, a degree of acidity attained in the pyloric stomach of the pig.

The above findings support the work of Common (1940) who showed that the recovery of ingested phytic acid in the droppings of pullets was greater when a 
particular ration was supplemented with calcium carbonate than when supplemented with calcium phosphate. It is also interesting that Marek, Wellmann \& Urbanyi (1935) found that when calcium carbonate in the diet of pigs was replaced by sodium phosphate the percentage of organic $P$ in the contents of the large intestine was reduced. These workers considered that the change in mineral supplement reduced the intestinal synthesis of organic $\mathrm{P}$ compounds. However, in view of the present work, it appears that the results of Marek et al. (I935) might well be explained by an increased hydrolysis of phytate $\mathrm{P}$ in the large intestine of the pigs receiving sodium phosphate in the diet.

It appeared that phytate hydrolysis also occurred in the stomach of pigs given a mineral supplement of calcium phosphate as it did with those given calcium carbonate (Moore \& Tyler, 1955), for the percentage of non-phytate, non-radioactive $P$ in the dry matter of the feed $(0.390)$ was less than in the contents of the first section of the stomach (mean 0.453 ) of pigs nos. 9 and 10.

\section{SUMMARY}

I. Pigs 9-10 weeks of age were fed on a diet containing $2 \%$ calcium phosphate. Two of the animals were slaughtered $4 \mathrm{~h}$ after receiving a single meal, the mineral supplement of which contained ${ }^{45} \mathrm{Ca}$ and ${ }^{32} \mathrm{P}$. $\mathrm{pH}$, total $\mathrm{Ca}$ and $\mathrm{P},{ }^{45} \mathrm{Ca}$ and ${ }^{32} \mathrm{P}$, and phytate $\mathrm{P}$ were determined in the contents of the various sections of the gastrointestinal tract. The tissues of the gastro-intestinal tract were also analysed for total $\mathrm{Ca}$ and $\mathrm{P}$ and ${ }^{45} \mathrm{Ca}$ and ${ }^{32} \mathrm{P}$.

2. ${ }^{45} \mathrm{Ca}$ and ${ }^{32} \mathrm{P}$ were included in the calcium-phosphate supplement of the diet of two more pigs for a period of Io days. On the I Ith day the radioactive calcium phosphate was replaced by inactive calcium phosphate. The pigs were slaughtered $4 \mathrm{~h}$ after receiving the morning feed on the $5_{5}$ th day. $\mathrm{pH}$, total $\mathrm{Ca}$ and $\mathrm{P},{ }^{45} \mathrm{Ca}$ and ${ }^{32} \mathrm{P}$ and phytate $\mathrm{P}$ were determined in the gastro-intestinal contents. The specific activity of $\mathrm{Ca}$ and $\mathrm{P}$ in the blood serum was also determined.

3. 'Two pigs given a ration containing $2 \%$ calcium phosphate were also killed $4 \mathrm{~h}$ after feeding to determine the solubility of $\mathrm{Ca}$ and $\mathrm{P}$ in the gastro-intestinal contents of animals given a mineral supplement of calcium phosphate.

4. The absorption of $\mathrm{Ca} 4 \mathrm{~h}$ after feeding was most active from the proximal fourth of the small intestine and of $\mathrm{P}$ from the proximal half. The most intensive absorption of $\mathrm{Ca}$ and $\mathrm{P}$ from the small intestine therefore took place at a point where the solubility of these elements in the contents of the small intestine was greatest.

5. Ca and $\mathrm{P}$ were secreted into the lumen of the upper small intestine but were reabsorbed from the lower segments of the small intestine.

6. Neither $\mathrm{Ca}$ nor $\mathrm{P}$ appeared to be excreted through the wall of the large intestine. Only small amounts of endogenous $\mathrm{Ca}$ and $\mathrm{P}$ were found in the contents of the lower intestine, but for reasons discussed it was concluded that the true endogenous Ca and $P$ in the contents of the large intestine would most certainly be less than was estimated by the technique used in the present experiment. Any faecal excretion of endogenous $\mathrm{Ca}$ and $\mathrm{P}$ would seem to be due to the incomplete reabsorption of the secreted $\mathrm{Ca}$ and $\mathrm{P}$ in the small intestine. 
7. When calcium phosphate was included in the diet of pigs hydrolysis of phytate $P$ occurred not only in the stomach but also in the large intestine.

8. The relationship between the results obtained from the present study and other work reported in the literature is discussed.

The authors wish to express their thanks to Dr N. S. Barron, Mrs D. Howell and Dr D. H. L. Rollinson who slaughtered the pigs and helped with the dissection, to Dr D. H. Tomlin for assistance and advice in the experiments with ${ }^{45} \mathrm{Ca}$ and ${ }^{32} \mathrm{P}$, and to $\mathrm{Mr}$ T. Pearson who was in charge of the experimental animals.

\section{REFERENCES}

Adolph, W. H. \& Liang, C.-C. (1941). F. biol. Chem. 137, 517.

Baylor, C. H., Van Alstine, H. E., Keutmann, E. H. \& Bassett, S. H. (1950). f. clin. Invest. 29,1 I 67.

Cohn, W. E. \& Greenberg, D. M. (1938). F. biol. Chem. 123, 185 .

Common, R. H. (1940). F. agric. Sci. 30, 113.

Gaunt, W. E., Griffith, H. D. \& Irving, J. T. (1941-2). F. Physiol. roo, 372.

Hagens, E. (1943). Nord. Med. 20, 1737.

Harrison, H. E. \& Harrison, H. C. (1951). J. biol. Chem. 188, 83 .

Hill, R. \& Tyler, C. (1954). F. agric. Sci. 44, 306.

Kjerulf-Jensen, K. (194I-2). Acta physiol. scand. 3 (suppl. 9 and 10), p. I.

Laskowski, M. (1937). Biochem. Z. 292, 319.

Lenkeit, W. (1931). Arch. Tierernähr. Tierz. 5, 376. Quoted in Nutr. Abstr. Rev. (1931-2), 1, 263.

L'Heureux, M. V., Tweedy, W. R. \& Zorn, E. M. (1949). Proc. Soc. exp. Biol., N. Y., 71, 729.

Lund, A. (1945). Beretn. Forsøgslab. Kbh. 218, 36. Quoted in Nutr. Abstr. Rev. (1946-7), 16, 614.

McCance, R. A. and Widdowson, E. M. (1939). Biochem. F. 33, 523.

Marek, J., Wellmann, O. \& Urbanyi, L. (1935). Mezögasdas kutatás. 8, 18 I.

Moore, J. H. \& Tyler, C. (1955). Brit. Y. Nutr. 9, 63.

Nicolaysen, R. (1934). Skand. Arch. Physiol. 69 (suppl.).

Nicolaysen, R. (1951). Acta physiol. scand. 22, 260.

'Trautmann, A. \& Kirchhoff, H. (1937). Arch. wiss. prakt. Tierheilk. 72, 361. Quoted in Nutr. Abstr. Rev. (1937-8), 7, 979 .

Wallace, H. D., Shirley, R. L. \& Davies, G. K. (I95I). F. Nutr. 43, 469. 